\title{
A Coin Trapped in Meckel's Diverticulum
}

\section{Meckel Divertikülünde Tutsak Bozuk Рara}

\author{
(iD Levent CANKORKMAZ
}

Sivas Cumhuriyet University Faculty of Medicine, Department of Pediatric Surgery, Sivas, Turkey

\begin{abstract}
Foreign body ingestion is a common problem among children. Most foreign bodies that have passed the esophagus will pass uneventfully through the intestinal tract. Foreign bodies that remain blocked in the narrower segments of the gastrointestinal tract require intervention. We herein report the case of a child who presented with a coin trapped in Meckel's diverticulum (MD). A 2-year-old boy was brought to our hospital 3 months after ingestion of coin. Physical examination showed no abdominal tenderness. Laboratory was normal. The foreign body appeared to be a coin located in the middle lower quadrant in the abdominal X-ray. Exploratory laparotomy was performed, and Meckel's diverticulum was discovered. The coin was detected in Meckel?'s diverticulum and it wedge resection were performed. After the operation, the patient had an uneventful recovery and started enteral feeding within 5 days. Early treatment of ingested foreign bodies in the gastrointestinal system is important in terms of preventing possible complications. The determination of the exact location of the coin, decision for intervention, and management may be difficult in cases with prolonged lodgment. The diagnosis of MD should be considered when there is a prolonged lodgment of a foreign body in the lower quadrant.
\end{abstract}

Keywords: Meckel, child, ingestion foregien body

\section{ÖZ}

Yabancı cisim yutulması çocuklar arasında yaygın bir sorundur. Özofagusu geçen yabancı cisimlerin çoğu bağırsak sisteminden sorunsuz bir şekilde geçecektir. Gastrointestinal sistemin daha dar segmentlerinde bloke kalan yabanci cisimler müdahale gerektirir. Burada Meckel divertikülünde (MD) sıkışmış bir bozuk para ile başvuran çocuk olgusunu sunuyoruz. İki yaşında erkek çocuk, bozuk para yutmasından 3 ay sonra hastanemize getirildi. Fizik muayenede karın hassasiyeti görülmedi. Laboratuvar normaldi. Yabancı cisim, karın grafisinde orta alt kadranda görünüyordu. Laparotomi yapıldı ve paranın MD'si olduğu saptandı ve divertikül rezeke edildi. Ameliyattan sonra hasta sorunsuz iyileşti ve 5 gün içinde oral beslenmeye başladı. Gastrointestinal sistemde yutulan yabancı cisimlerin erken tedavisi, olası komplikasyonların önlenmesi açısından önemlidir. Yabancı cismin uzun süre aynı yerde kaldığı vakalarda cismin tam yerini, müdahale kararını ve yönetimi belirlemek zor olabilir. Yabancı cismin alt kadranda uzun süre sabit kaldığı durumunda Meckel divertikülü akla gelmelidir.

Anahtar Sözcükler: Meckel, çocuk, yabancı cisim yutma

\section{Introduction}

Foreign body ingestion is a common problem in children. Most foreign bodies that cross the esophagus pass through the gastrointestinal tract without any problems. Of foreign bodies 80$90 \%$ entering the small intestine are excreted spontaneously in the stool (1). Foreign bodies blocking in narrower segments of the gastrointestinal tract (10-20\%) require non-surgical interventions, while approximately $\leq 1 \%$ require surgical intervention (2).

In this case report, a child who were admitted to our hospital with a history of swallowing coin 3 months ago was presented. The

Address for Correspondence: Levent CANKORKMAZ, Sivas Cumhuriyet University Faculty of Medicine,

Received: 29.05 .2020

Department of Pediatric Surgery, Sivas, Turkey

Accepted: 11.06 .2020 
coin was found to have settled in Meckel's diverticulum (MD) during the exploration. To our knowledge, there are few reports of foreign body stuck in MD in the pediatric literature.

\section{Case Report}

A two-year-old boy was admitted to our hospital with a history of swallowing foreign body (coin) 3 months ago. It was learned that the patient was under follow-up in an external center for three months and was referred to our pediatric surgery outpatient clinic because the coin did not move in the control direct radiographs.

No pathology was detected in the physical examination of the patient. Abdominal examination did not reveal tenderness or defense. A radiopaque foreign body (coin) was detected in the middle lower quadrant of the patient's standing direct abdominal $\mathrm{X}$-ray (Figure 1). Laboratory values were evaluated as normal. Since the history of foreign body ingestion was three months ago, the family was informed and the surgery was planned. It was observed that there was no displacement in the control standing direct abdominal X-ray of the patient who was prepared for the operation under elective conditions, and that the coin persisted in the lower abdominal quadrant.

During the exploration under general anesthesia, MD was detected approximately $50 \mathrm{~cm}$ proximal to the ileocecal valve. When the exploration was continued, the diagnosis was made by palpating the coin in the diverticulum. The bowel was repaired by performing wedge resection of MD. Macroscopic examination of the resected specimen revealed a coin stuck in MD (Figure 2a, b). The patient, who had an uneventful recovery after the operation, started oral feeding within 5 days and was discharged on the $7^{\text {th }}$ day.

\section{Discussion}

Foreign body ingestion is a common problem in the pediatric age group. Early diagnosis and intervention are important because of possible serious complications of swallowed foreign bodies such as mucosal erosion, airway obstruction or intestinal perforation (3). In young children, the time and type of foreign body ingestion cannot always be determined exactly. Although Chauvin et al. (4) have argued that enteroscopy or surgery should be considered for the removal of dangerous foreign objects such as sharp, pointed or elongated objects, batteries or magnets that cross the ligament of Treitz, there is no consensus in the literature. Since the structure of the foreign body is important for the management of the follow-up, the coin must be distinguished from the batteries (2). While straight-edged foreign bodies usually do not cause a serious condition, emergency intervention is required if the foreign body is a sharp object (3). It is difficult to make an intervention decision in cases where the foreign body in the gastrointestinal tract remains in the same localization for a long time. Daily stool observation and abdominal radiographs are required to monitor the progression of foreign bodies, such as coins, that have a lower risk of causing perforation through the gastrointestinal tract. However, the patient's family should
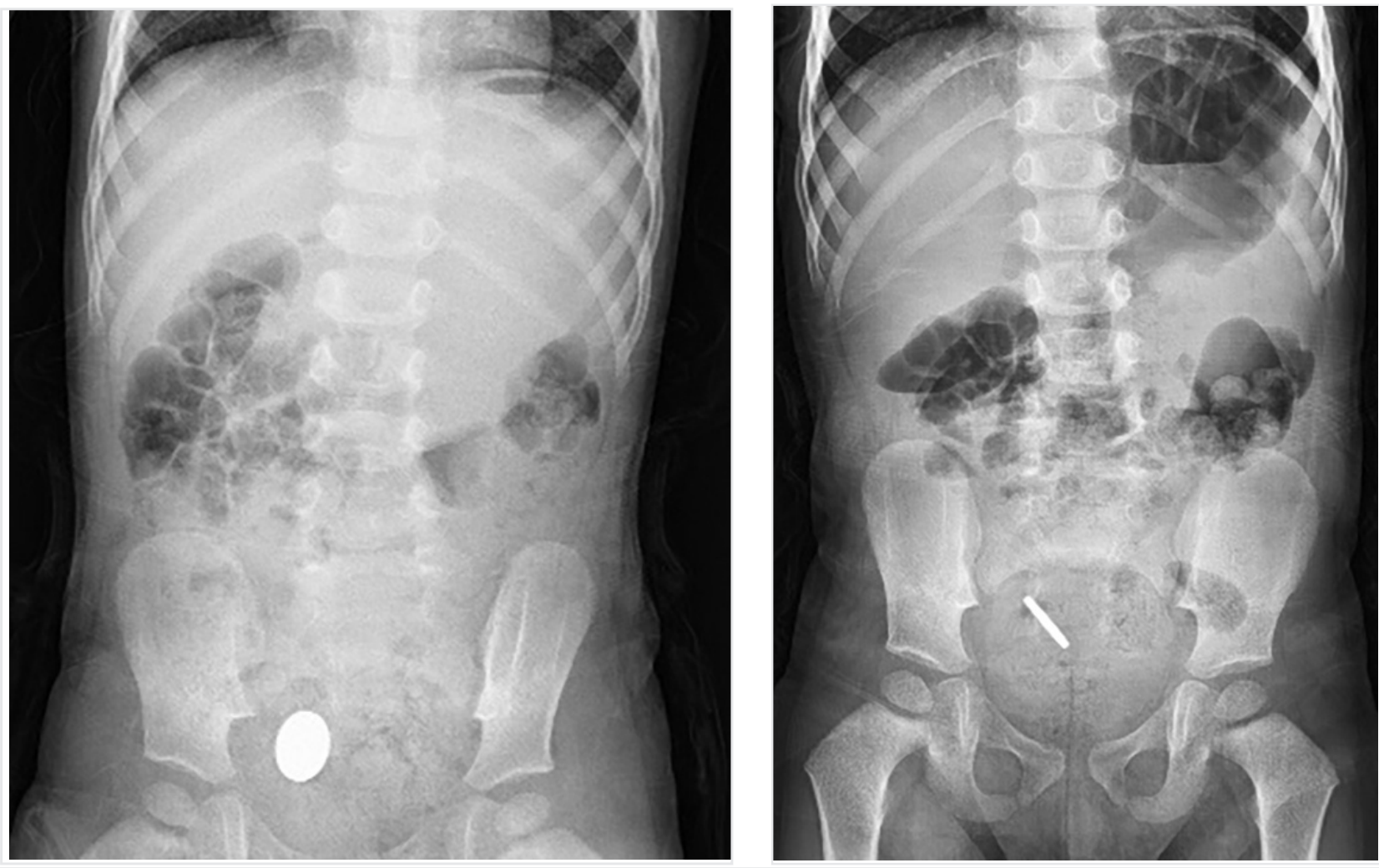

Figure 1. Patient's standing direct abdominal X-ray view showing a coin. 


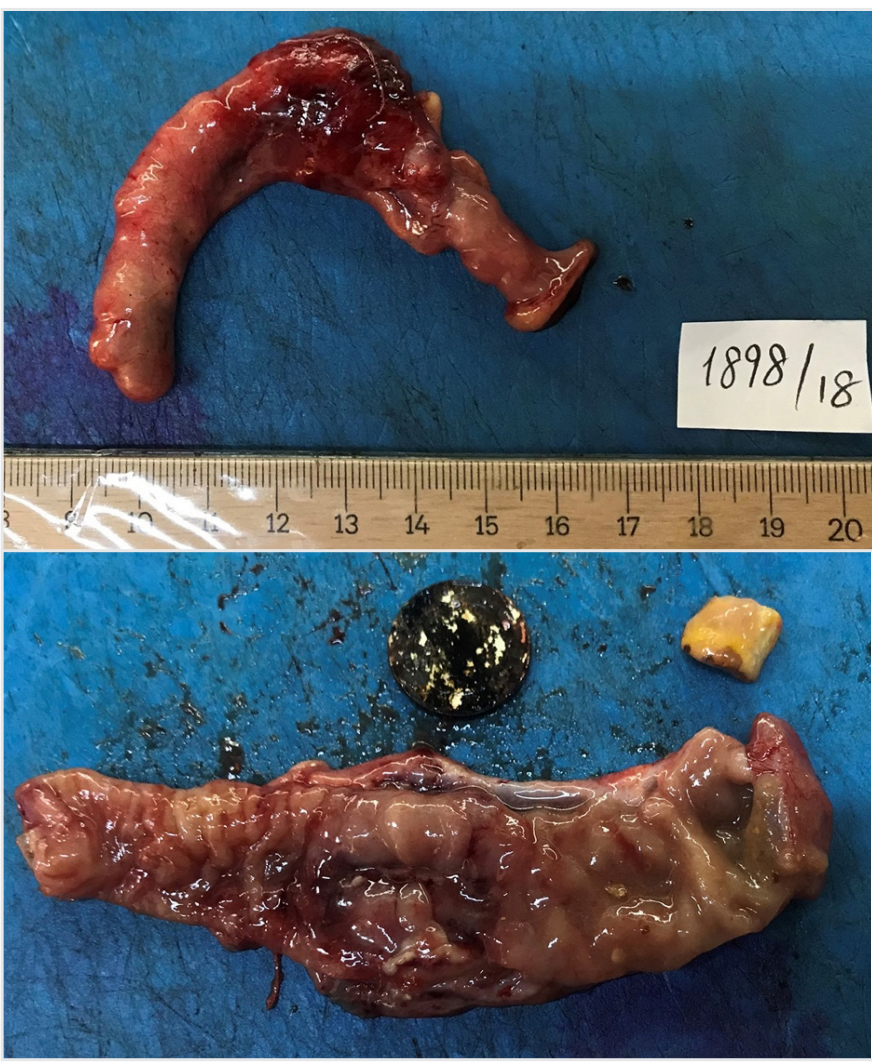

Figure 2a,b. Coin trapped within Meckel's diverticulum. This study was presented as poster at the $6^{\text {th }}$ World Congress of Pediatric Surgery - WOFAPS 2019, 1-3 November 2019, Doha, Qatar.

be aware of the clinical signs of perforation and obstruction in this period (2).

Meckel's diverticulum is a remnant of the omphalomesenteric (vitelline) duct. $\mathrm{MD}$ has potential complications such as intestinal obstruction, gastrointestinal bleeding, or inflammation of the diverticulum with or without perforation (5). While the prevalence of $\mathrm{MD}$ is between $0.3-2.9 \%$ in the general population, the rate found in autopsy studies is $1.2 \%$ (5). In the literature, there are several case reports of puncture or occlusion of MD with disc pillars, phytobezoars, fish bones, chicken bones and needles in children and adults (6-9). In the three case reports of coin located in MD, which was detected in the English literature review, two patients were children and one patient was a 25-yearold woman. An adult patient presented with perforation, while the 19-month-old patient presented with abdominal pain and vomiting. Karadeniz Cerit et al. (2) presented their laparoscopic approach to an asymptomatic 10-year-old patient like our patient $(10,11)$.
In particular, it may be difficult to determine the exact location of the foreign body, which does not move for a long time, and to make a follow-up or intervention decision (2). In such cases, it is not easy to find coins with X-ray images. We think that MD is a pathology that should be kept in mind, especially in foreign bodies that do not change their localization for a long time in the lower quadrant.

\section{Ethics}

\section{Informed Consent:}

Peer-review: Externally peer reviewed.

Financial Disclosure: The author declared that this study received no financial support.

\section{References}

1. Nandi P, Ong GB. Foreign body in the oesophagus: review of 2394 cases. Br J Surg 1978;65:5-9.

2. Karadeniz Cerit K, Kalyoncu A, Erbarut İ, Kıyan G, Dağlı TE. Laparoscopic approach for removing a coin trapped in Meckel's diverticulum. Ulus Travma Acil Cerrahi Derg 2017;23:438-40.

3. Aydoğdu S, Arikan C, Cakir M, Baran M, Yüksekkaya HA, Saz UE, et al. Foreign body ingestion in Turkish children. Turk J Pediatr 2009;51:127-32.

4. Chauvin A, Viala J, Marteau P, Hermann P, Dray X. Management and endoscopic techniques for digestive foreign body and food bolus impaction. Dig Liver Dis 2013;45:529-42.

5. Ivatury RR. Meckel's diverticulum and the eponymous legend. J Trauma Acute Care Surg 2019;87:451-5.

6. Escobar MA, Tiu MC, Yotter CN, Han MT. Button battery perforating a Meckel's diverticulum in an asymptomatic child: An exception to recommendations for management. Journal of Pediatric Surgery Case Reports 2013;1:132-5.

7. Karaman A, Karaman I, Erdoğan D, Cavuşoğlu YH, Aslan MK, Varlikli O, et al. Perforation of Meckel's diverticulum by a button battery: report of a case. Surg Today 2007;37:1115-6.

8. Mares AJ, Finaly R, Mordechai J, Motovic A. "Pantaloon" phytobezoar: an unusual cause of intestinal obstruction associated with Meckel's diverticulum. Isr J Med Sci 1993;29:683-5.

9. ROESSEL CW. Perforation of meckel's diverticulum by foreign body: case report and review of the literature. Ann Surg 1962;156:972-5.

10. Purkayastha A, DeWitt W, Koberlein N. Foreign body in a Meckel's diverticulum. JAMA 1984;251:2659.

11. Halverson JM, Butterman MK, Legier JF, Mann WJ Jr, Hoefer RA Jr. Perforation of a Meckel's diverticulum caused by ingestion of a coin. South Med J 1994;87:823-4. 